Juan Carlos Vergara-Schmalbach,

Francisco Javier Maza-Avila

Colombia

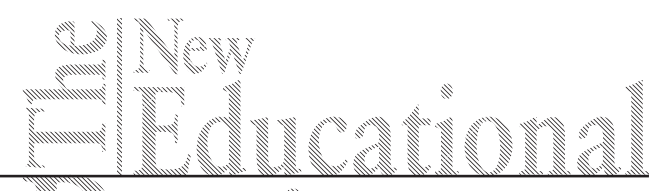

\title{
Relationship among Students' Perceptions, Satisfaction and Future Behavioral Intentions at Universities in Cartagena, Colombia
}

DOI: 10.15804/tner.2015.41.3.11

\begin{abstract}
The paper proposes a theoretical model to assess the factors affecting students' satisfaction of their university and their future behavioral intentions. The proposed model was validated by empirical or case research, applied at three Colombian universities (public and private) in Cartagena. A 19-item questionnaire was given to a random sample of 400 students, and was solved by the Structural Equation Modeling (SEM). Results showed that the students' perceptions of the universities analyzed affected their satisfaction level and this, in turn, affected their future intentions. Perceived value pricing did not have a significant effect on satisfaction. The model was validated using the most common fit indices. The results presented a statistically valid model, whose main result is the identification of a significant causal effect among the students' perceptions, satisfaction and future behavioral intentions in the universities analyzed. There was not a significant difference in results between the public and private universities.
\end{abstract}

Keywords: Structural Equation Modeling, perceptions, satisfaction, student's university, future behavioral intentions

\section{Introduction}

Nowadays it is in vogue to implement integrated management systems and accreditation processes at higher education institutions in Colombia to assure the quality of the academic and administrative service. At public universities, the inte- 
grated systems are a standard, required by government agencies. This trend causes universities to focus on service quality and customer orientation to identify the key drivers affecting customer satisfaction. With this knowledge, administrators at public universities would be able to guide strategies to continuously strengthen administrative processes. In this paper, the authors present the results of research on a theoretical model to assess the factors affecting university satisfaction and future behavioral intentions and its causal effects. The proposed model was validated by empirical or case research, applied at three Colombian universities in Cartagena (University of Cartagena, University of San Buenaventura and Technological University of Bolívar), applying the Structural Equation Modeling to determine causal relationships. The proposed model was based on the causal diagram created by Vergara-Schmalbach and Quesada (2011), and adapted by the proposal made by Ho (1999).

\section{Literature Review}

Understanding in detail the variables that affect satisfaction will allow researchers and entrepreneurs to develop strategies to improve both satisfaction and retention of customers and in turn, motivate their intention to re-purchase (Cronin and Taylor, 1992; Fornell, 1992; Gronroos, 1982). Service characterization is a complex task founded on the nature of the service, in the difficulty of the standardization process, and the inseparability of production and consumption (Parasuraman, Zeithaml and Berry, 1985; Zeithaml, 1981). Heizer and Render (2009) argue that a service is an intangible product, produced and consumed simultaneously, and has a strong customer interaction. Service should be treated as a process, whose starting point begins with resource planning (employees, physical resources, methods, technology and customers), the sequence of activities and the objectives (Grönroos, 2001). Therefore, the quality of service will result from the difference between user expectations (before receiving services) and user perceptions (after receiving services).

Cronin and Taylor $(1992 ; 1994)$ built an alternative model that does not include the measurement of expectations (only evaluates perceptions) called SERVPERF (Service Performance), which was proved to be superior (Barrera and Reyes, 2003; Jain and Gupta, 2004; McAlexander, Kaldenberg, and Koenig, 1994). It uses the same number of questions (items) and the latent variables as in the SERVQUAL scale. This proposal established two alternative analyses in the studies on service quality: one based on a disconfirmation paradigm and the other based on only the evaluation of perceptions (Salvador-Ferrer, 2009), the latter being the most commonly used scheme for assessing perceptions and satisfaction. 


\section{Assessing students' perceptions and satisfaction}

Studies measuring student satisfaction of universities through the assessment of perceptions have focused on aspects related to teacher performance, infrastructure, reliability and quality resources or quality equipment, customer care services and maintenance costs (Tuition Costs). Vergara-Schmalbach and Quesada (2011) conducted a pilot study at a public university, which determined that there is a direct relationship among perceptions, service quality, satisfaction and future intentions of the student. In this study, perceptions also had an indirect effect on future intentions (e.g., to recommend the university to others and to continue studying at the university). Likewise, in an empirical case study developed with Structural Equation Modeling, Sumaedi, Bakti and Metasari (2011) show that price and perceived quality have a significant influence on student satisfaction.

Furthermore, Oldfield and Baron (2000) claimed that the interaction between teachers and students is the central element of the education service, which is an important indicator of quality and an element to be considered when evaluating perceptions. Abdullah (2006) mentions four aspects (perceptions) to be considered in a satisfaction survey on students: non-academic aspects (administrative), academic aspects, reliability (efficiency and compliance in service) and empathy (student interest). Kao (2007), in a set of perceptions analyzed in a sample of 560 students, found, coinciding with the other authors mentioned in this review, that student interaction (contact between teachers and students) is the perception that influences their overall level of satisfaction the most. These relationships could be affected by social or economic conditions; Martinez and Perez (2007) affirm that the quality perceived by students affects public and private schools differently .

\section{Theoretical model proposed}

From the original model proposed by Oh (1999), adapted to this study, the authors propose the following hypothetical scheme of relationships among latent variables (Figure 1), allowing for identifying the degree of relation (covariance) between perceptions, perceived quality, student satisfaction, intention to continue studying and word of mouth. What is also included is the perception of the cost of tuition and its possible effect on the perceived service quality and student satisfaction.

Taking into account this model, each of the interactions in the causal diagram must represent a statistical hypothesis (Table 1). 


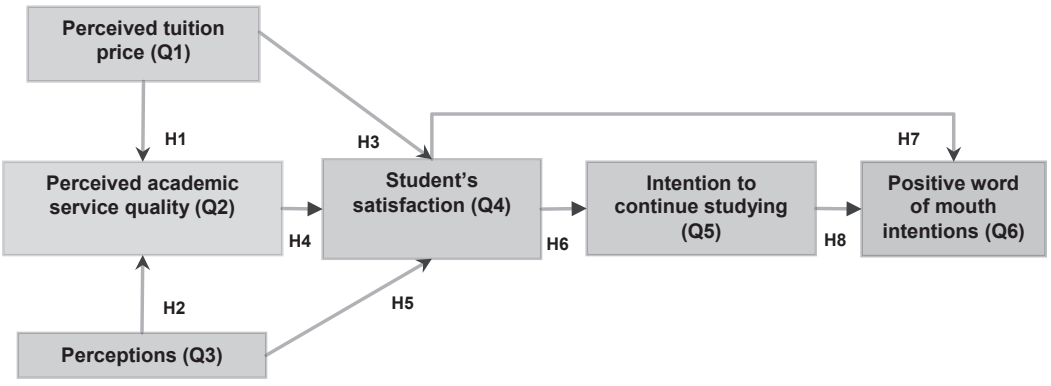

Figure 1. Theoretical model proposed

Table 1. List of Hypotheses

\begin{tabular}{l}
\hline Hypothesis \\
\hline H1: Perceived tuition price positively influences perceived academic service quality \\
\hline H2: Perceptions positively influence perceived academic service quality \\
\hline H3: Perceived tuition price positively influences the student's satisfaction \\
\hline H4: Perceived academic service quality positively influences the student's satisfaction \\
\hline H5: Perceptions positively influence the student's satisfaction \\
\hline H6: The student's satisfaction positively influences the intention to continue studying \\
\hline H7: The student's satisfaction positively influences word of mouth intentions \\
\hline H8: Intention to continue studying positively influences positive word of mouth intentions
\end{tabular}

\section{Research Methodology}

\section{Survey and sampling}

The empirical study was conducted at three major universities located in Cartagena: University of Cartagena (public), Technological University of Bolivar (private) and University of San Buenaventura (private). These universities were classified in two populations: public and private. The combined population of the three universities under study is approximately 14,852 enrolled students, of whom the University of Cartagena has 9,760, the Technological University of Bolivar has 4,092 and the University of San Buenaventura has about 1,000 students. A sample of 387 students (between the third and tenth semester) was selected, for a max- 
imum error equal to $\pm 5 \%$. However, according to Schumacker and Lomax, in the Structural Equation Models, researchers often need a larger sample size than those obtained with traditional sampling formulas in order to maintain and obtain a stable estimate of the parameters and standard errors (Schumacker and Lomax, 2004). Consequently, Hoelter (1983) proposes a critical sample size not fewer than 200 people per a population group studied, implying (in this case) an adjustment of the total sample size, raising it to 400 students (200 students per group). Table 2 shows the actual sample size, following the above recommendations. With the adjusted sample size, a maximum error of $\pm 4.86 \%$ was achieved.

Table 2. Survey Distribution

\begin{tabular}{lc}
\hline University & Sample \\
\hline University of Cartagena (Public) & 200 \\
\hline Technological University of Bolivar (Private) & 100 \\
\hline University of San Buenaventura (Private) & 100 \\
\hline Total sample size & 400 \\
\hline
\end{tabular}

\section{Measures and questionnaire design}

The data collected was based on a questionnaire design composed of 19 items, of which 14 questions were detached keys representing observed variables of the model (the first five items correspond to respondent profile). The perception on the tuition price paid by the student, related to the service received, was measured considering a 6-point Likert scale, where 1 is low and 6 high. 9 questions, using the same 6-point Likert scale, evaluated perceptions: teacher quality, academic materials, pedagogical tools used by teachers, teaching techniques, service offered by academic department, office management services, productivity research, physical infrastructure and audiovisual media.

The perceived academic service quality was rated using a 6-point scale, where 1 represented much worse than expected and 6 much better than expected. The same scale was used to determine the degree of satisfaction, where 1 equals very dissatisfied and 6 very satisfied. Regarding the intention to continue studying, 1 refers to very unsatisfied and 6 to completely satisfied; and positive word of mouth intentions were evaluated under the range of very unlikely to very likely ( 1 and 6, respectively). Table 3 shows the observed variables proposed, according to the numbering of the hypotheses presented in Figure 1, in which the latent or unobservable variable "perceptions" is measured by observable variables numbered 3-11. 
Table 3. List of observable variables (questionnaire design)

\begin{tabular}{ll}
\hline Observable Variables & \\
\hline P_1. Perceived tuition price & P_8. Office management services \\
\hline P_2. General academic service quality & P_9. Productivity research \\
\hline P_3. Teacher quality & P_10. Physical infrastructure \\
\hline P_4. Academic materials & P_11. Audiovisual media \\
\hline P_5. Pedagogical tools used by teachers & P_12. Degree of satisfaction \\
\hline P_6. Teaching techniques & P_13. Intention to continue studying \\
\hline P_7. Service offered by academic department & P_14. Positive word of mouth intentions \\
\hline
\end{tabular}

Table 4 shows the list of latent variables (variables which are not measured directly) used in the model.

Table 4. List of latent variables

\begin{tabular}{ll}
\hline Latent variables \\
\hline Q_1. Perceived tuition price & Q_4 Students' satisfaction \\
\hline Q_2. Perceived academic service quality & Q_5 Intention to continue studying \\
\hline Q_3. Perceptions & Q_6 Positive word of mouth intentions \\
\hline
\end{tabular}

To evaluate the validity and reliability of the rating scale, the Cronbach alpha coefficient was used on the total sample size, with an average result of 0.75 , demonstrating good reliability.

\section{Analysis}

The proposed model in Figure 1 was analyzed using the LISREL 8.80 software. Ordered data established a general structure of the relationship between the observable variables and the latent variables applicable to the public and private universities. This analysis technique estimated the simultaneous multiple regression in a single framework. In particular, all direct and indirect relationships in the model were estimated simultaneously; therefore, the method presented all the interrelationships between the variables in the same context. 


\section{Research Results}

Descriptive analysis of the profile showed that $40.50 \%$ of the respondents were aged between 18 and 20 years, while $50 \%$ were aged between 20 and 22 years. Overall, $66.50 \%$ of them had a household income level over 700,000 Colombian pesos (COP), followed by $12.5 \%$ with anywhere between 600,001 and 700,000 COP and only $4.75 \%$ of the respondents reported having a household income less than 400,000 COP.

Most of the students of the analyzed public university (87.5\%) belonged to socioeconomic strata 1 and 2 , which are the lowest. In contrast, the students at the private universities (65.50\%) belonged to strata 3, 4 and 5, which are the highest. At the public university, the paid tuition price per semester by the surveyed students averaged $383,470.54 \mathrm{COP}$, while at the private universities, the average was $3,207,846.75$ COP. As shown in Table 5, the averages for the observed variables at the public university fall within the range between 3.1 and 5.25 with standard deviations between 0.95 and 1.48 .

Table 5. Descriptive statistic (Public University)

\begin{tabular}{|c|c|c|c|c|c|}
\hline Latent Variables & $\begin{array}{c}\text { Observable } \\
\text { Variables }\end{array}$ & Averages & Deviations & $\begin{array}{l}\text { Minimum } \\
\text { value }\end{array}$ & $\begin{array}{l}\text { Maximum } \\
\text { value }\end{array}$ \\
\hline Perceived tuition price & P1 & 3.74 & 1.48 & 1 & 6 \\
\hline $\begin{array}{l}\text { Perceived academic service } \\
\text { quality }\end{array}$ & P2 & 4.61 & 0.95 & 1 & 6 \\
\hline \multirow{9}{*}{ Perceptions } & P3 & 4.62 & 1.00 & 1 & 6 \\
\hline & $\mathrm{P} 4$ & 4.27 & 0.98 & 1 & 6 \\
\hline & P5 & 3.86 & 1.06 & 1 & 6 \\
\hline & P6 & 3.87 & 1.00 & 1 & 6 \\
\hline & P7 & 3.93 & 1.34 & 1 & 6 \\
\hline & P8 & 3.94 & 1.21 & 1 & 6 \\
\hline & P9 & 4.39 & 1.18 & 1 & 6 \\
\hline & $\mathrm{P} 10$ & 3.10 & 1.40 & 1 & 6 \\
\hline & P11 & 3.30 & 1.35 & 1 & 6 \\
\hline Student satisfaction & P12 & 4.84 & 0.96 & 2 & 6 \\
\hline $\begin{array}{l}\text { Intention to continue } \\
\text { studying }\end{array}$ & P13 & 5.08 & 1.10 & 1 & 6 \\
\hline $\begin{array}{l}\text { Positive word of mouth } \\
\text { intentions }\end{array}$ & P14 & 5.25 & 0.96 & 1 & 6 \\
\hline
\end{tabular}


At the private universities, the averages were obtained for the observed variables in the range between 4.26 and 5.02 with standard deviations between 0.95 and 1.36 (Table 6). In general, both the public university and the private universities had similar ratings on the questions related to the model.

Table 6. Descriptive statistics (Private Universities)

\begin{tabular}{lccccc}
\hline \multirow{2}{*}{ Latent Variables } & $\begin{array}{c}\text { Observable } \\
\text { Variables }\end{array}$ & Averages & Deviations & $\begin{array}{c}\text { Minimum } \\
\text { value }\end{array}$ & $\begin{array}{c}\text { Maximum } \\
\text { value }\end{array}$ \\
\hline Perceived tuition price & P1 & 4.56 & 1.18 & 1 & 6 \\
\hline $\begin{array}{l}\text { Perceived academic service } \\
\text { quality }\end{array}$ & P2 & 4.82 & 0.98 & 2 & 6 \\
\hline \begin{tabular}{l} 
Perceptions \\
\cline { 2 - 6 }
\end{tabular} & P3 & 4.82 & 0.95 & 1 & 6 \\
\cline { 2 - 6 } & P4 & 4.67 & 0.98 & 2 & 6 \\
\cline { 2 - 6 } & P6 & 4.30 & 1.13 & 1 & 6 \\
\cline { 2 - 6 } & P7 & 4.35 & 1.06 & 1 & 6 \\
\cline { 2 - 6 } & P9 & 4.41 & 1.13 & 1 & 6 \\
\cline { 2 - 6 } & P10 & 4.62 & 1.19 & 1 & 6 \\
\cline { 2 - 6 } & $\mathrm{P} 11$ & 4.77 & 1.31 & 1 & 6 \\
\hline $\begin{array}{l}\text { Student satisfaction } \\
\text { Intudying }\end{array}$ & $\mathrm{P} 12$ & 4.96 & 0.98 & 2 & 6 \\
\hline $\begin{array}{l}\text { Positive word of mouth } \\
\text { intentions }\end{array}$ & $\mathrm{P} 13$ & 5.02 & 1.12 & 1 & 6 \\
\hline
\end{tabular}

Applying the D'Agostino-Pearson omnibus test (normality test) to the observable variables, the assumption of normality was rejected. The non-normality affects the results in some methods (Schumacker and Lomax, 2004). If the data are associated with a probability distribution, there would be the possibility of causing a "serious violation" during method development (Kline, 2011). In this sense, the ULS (Unweighted Least Squares) method was applied, which is recommended in this case because the normality assumption was not taken into account.

\section{Model development}

Using Lisrel software, covariances between the latent and observable variables were obtained. At this point, the confidence was proved for each covariance obtained between the latent variables in both models (public and private) by the 
goodness of fit test (with a 95\% confidence level and $t>|1.96|$ ). Except for two causal paths, all the other hypothesized relationships appeared to be statistically significant for both types of universities, as illustrated in Figure 2 and Figure 3.

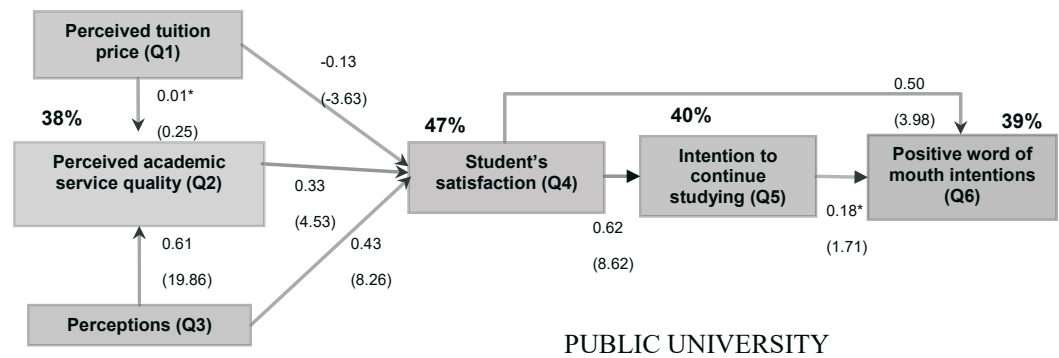

Figure 2. Developed causal models for public university

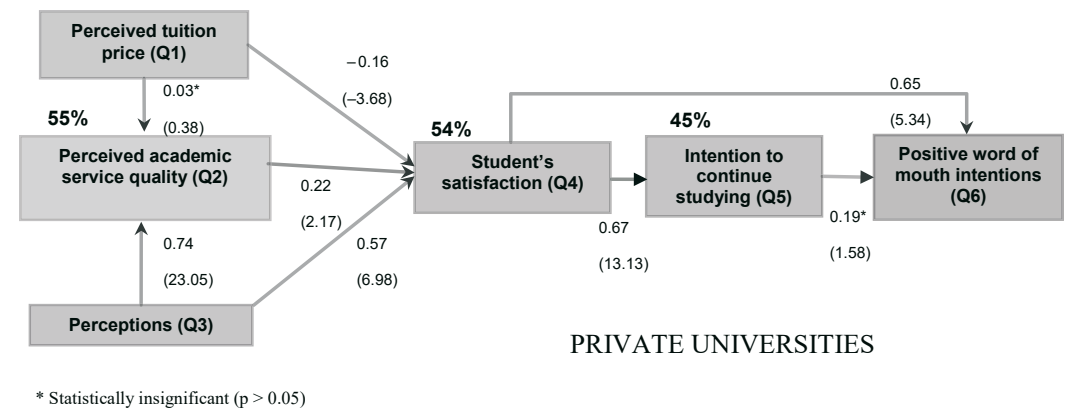

Figure 3. Developed causal models for private universities

Analyzing the relationship between the latent variables in the case of the public university, the strongest causal relationship occurred between satisfaction (Q4) and intention to continue studying (Q5) with the covariance of 0.62 . Likewise, the quality of perceived academic service (Q2) was affected by perceptions (Q3), which in turn affected satisfaction (Q4) at 0.33 . In this vein, satisfaction affected the intention to recommend the university (Q6) with the covariance of 0.50 between the two.

On the model proposed for the private universities, the highest covariance (0.74) was found to occur between the variables of perceptions and perceived academic service quality, followed by the relationship between satisfaction and intention to continue studying (0.67). Also, a significant effect was observed 
between satisfaction and positive word of mouth intentions with the covariance of 0.65 . Significantly, the covariance explained the degree to which a variable affects another one (on the fixed scale of 1 to 6). For example, if 1 point was increased for perceptions (Q3), this would affect the perceived academic service quality (Q2) at the public university by 0.61 and by 0.74 at the private universities. Also, if the satisfaction (Q4) was increased by 1 point, the intention to continue studying (Q5) would grow by 0.62 and the positive word of mouth intentions (Q6) by 0.50 in the case of the public university. For the private universities, the same increment would grow by 0.67 for the intention to continue studying and 0.65 for the intention to recommend the university. The perceived tuition price (Q1) did not present a significant effect on the perceived academic service quality at any of the universities studied. Similarly, there are variables that would be affected indirectly by the effect of other variables. For example, the intention to continue studying (Q5) and the intention to recommend the university (Q6) could be affected by the perceptions of students (Q3).

The results of the explained variance could also be seen in Figures 2 and 3. Thus, within the model of the public university, $47 \%$ of the variation in student satisfaction was explained by the perceived academic service quality, perceived price of tuition and students' perceptions. $40 \%$ of the intention of further study was supported by satisfaction and $39 \%$ of the variance in the intention to recommend the university was a result of user satisfaction and intention to continue studying. The same analysis applies to the model solved at the private universities.

\section{Validity of structural equation modeling}

Since the X2 obtained from both models (261.98 and 312.18 in the public and private models, respectively) was elevated, yielding a value of less than 0.05 , a high value of $\mathrm{X} 2$ shows that there is a significant difference between theory behavior and the case results (Schermelleh-Engel, Moosbrugger and Müller, 2003). It is pertinent to use the following indicators to validate the model:

- The reason $\mathrm{X} 2 / \mathrm{df}$ ( $d f$ is the model degree of freedom)

- GFI (Goodness of Fit Index)

- AGFI (Adjusted Goodness of Fit Index)

- NFI (Normed Fit Index)

- NNFI (Non-Normed Fit Index)

- SRMR (Standardized Root Mean Square Residual)

These indices demonstrate the validity of structural equation modeling (Nevitt, Hancock and Taylor, 2012; Steiger, 2007). As can be seen in Table 7, the data was within the acceptable range, validating the two proposed models. 
Table 7. Fit Indices

\begin{tabular}{lccc}
\hline \multicolumn{1}{c}{ Indices } & $\begin{array}{c}\text { Recommended } \\
\text { range }\end{array}$ & $\begin{array}{c}\text { Public } \\
\text { university }\end{array}$ & $\begin{array}{c}\text { Private } \\
\text { university }\end{array}$ \\
\hline$X^{2} / d f$ & $2.00-5.00$ & 3.85 & 4.59 \\
\hline GFI (Goodness of Fit Index) & $>0.95$ & 0.97 & 0.98 \\
\hline AGFI (Adjusted Goodness of Fit Index) & $>0.90$ & 0.96 & 0.97 \\
\hline NFI (Normed Fit Index) & 1.00 & 1.00 & 1.00 \\
\hline NNFI (Non-Normed Fit Index) & $>0.95$ & 1.03 & 1.02 \\
\hline SRMR (Standardized Root Mean Square Residual) & $<0.08$ & 0.071 & 0.063 \\
\hline
\end{tabular}

\section{Discussion and conclusions}

In the available literature, it is difficult to find similar cases implementing the proposed model by Oh (1999), which excludes the expectations because they have a high level of subjectivity and it is not applicable in long-term service, in higher education. However, the presented model added some relationships between the latent variables, enriching the causal analysis, in addition to the model adaptation by Quesada and Vergara-Schmalbach (2011). Some of the assumptions of both models coincided significantly, confirming the relationship between students' perceptions and the perceived academic service quality, the perceptions and satisfaction, and between the satisfaction and the intention to continue studying (Vergara-Schmalbach and Quesada, 2011). In turn, it confirmed the conclusion that the perceived price variable has no significant effect on the perceived quality, and even its relationship with student satisfaction is not significant at any of the universities. In contrast to the results obtained by Mancebón, Martinez and Perez (2007), no significant differences were found in favor of the private universities.

In this study, an adjusted proposed model was applied, adapted to the education sector, in order to assess the quality of service and satisfaction of students at public and private universities in the city of Cartagena, using a structural equation model (Oh, 1999). From this model, the degree of relationship was established between the prices perceived by the student, the perceived academic service quality, perceptions, user satisfaction, intention to continue studying and intention to recommend the university (positive word of mouth intentions). The proposed scheme showed that the structural equation models were a feasible tool for the evaluation of the quality of service applied to universities. Furthermore, it gives a reasonable explanation of the value of the explained variance of the other variables. Of the eight hypotheses pro- 
posed at the beginning of the paper (Table 1), six were accepted. The amount paid for tuition did not affect the perceived quality in either case; perhaps it motivated, in part, because the payment of tuition was usually done by a family member and not the student. Additionally, the intention to continue studying is not related to the intention to recommend the university. Moreover, the strong relationship between perceptions and their effect on the perceived academic service quality and student satisfaction at the public and private universities should be highlighted. If this indicator is improved, the greater satisfaction of students will increase the indicator of intent to further study and to recommend the institution to others.

Possible further research could involve a study enlargement by including more universities (in different contexts), set to a critical value to characterize general satisfaction. In addition, it is advisable to check the absence of a price effect of tuition on the perceived service quality, perceived academic and student satisfaction, for this could have significant managerial implications for higher education institutions in the country.

\section{References}

Abdullah, F. 2006. Measuring service quality in higher education: three instruments compared. International Journal of Research \& Method in Education 29, no. 1: 71-89. doi:10.1080/01406720500537445

Barrera, R., and Reyes, M. 2003. Análisis comparativo de las escalas de Medición de la calidad del servicio. Las XIII Jornadas Hispano Lusas de Gestión Científica: La Empresa Familiar en un Mundo Globalizado. Lugo: Universidad de Sevilla.

Cronin, J.J., and Taylor, S.A. 1992. Measuring Quality: A Reexamination and Extension. Journal of Marketing 56, no. 3: 55-68.

Cronin, J., and Taylor, S. 1994. SERVPERF versus SERVQUAL: reconciling performance-based and perceptions-minus-expectations measurement of service quality. The Journal of Marketing 58, no. 1: 125-131. Retrieved from http://www.jstor.org/ stable/10.2307/1252256

Fornell, C. 1992. A National Customer Satisfaction Barometer: The Swedish Experience. Journal of Marketing 56, no. 1: 6-21.

Gronroos, C. 1982. Strategic Management and Marketing in the Service Sector. Helsinki: Swedish School of Economics and Business Administration.

Grönroos, C. 2001. The perceived service quality concept-a mistake? Managing Service Quality 11, no. 3: 150-152. Retrieved from http://www.emeraldinsight.com/journals. htm?articleid $=842727 \&$ show $=$ abstract

Heizer, J., and Render, B. 2009. Dirección de la producción y de operaciones. Madrid: Pearson Prentice Hall.

Hoelter, D. 1983. The analysis of covariance structures: Goodness-of-fit indices: Sociological Methods and Research. Sociological Methods and Research 11, no. 1: 324-344. 
Jain, S., and Gupta, G. 2004. Measuring service quality: SERVQUAL vs. SERVPERF scales. Vikalpa 29, no. 2: 25-37.

Kao, T. 2007. University Student Satisfaction : An Empirical Analysis. Brayford Pool: Lincoln University.

Kline, R.B. 2011. Principles and Practice of Structural Equation Modeling. New York: The Guilford Press.

Mancebón-Torrubia, M.J., Martínez-Caraballo, N., and Pérez-Ximénez, D. 200). Un análisis de la calidad percibida por los estudiantes en los centros públicos y privados de enseñanza secundaria. XVI Jornadas de la Asociación de Economía de la Educación. Granada: Universidad de las Palmas de Gran Canaria.

McAlexander, J.H., Kaldenberg, D.O., and Koenig, H.F. 1994. Service quality measurement. Journal of health care marketing 14, no. 3: 34-40.

Nevitt, J., Hancock, G.R., and Taylor, P. 2012. Improving the Root Mean Square Error of Approximation Conditions Nonnormal for in Structural Equation Modeling. The Journal of Experimental Education 68, no. 3: 251-268.

Oh, H. 1999. Service quality, customer satisfaction, and customer value: A holistic perspective. Hospitality Management 18, no. 1: 67-82.

Oldfield, B.M., and Baron, S. 2000. Student perceptions of service quality in a UK university business and management faculty. Quality Assurance in education 5, no. 1: 85-95.

Parasuraman, A., Zeithaml, V.A., and Berry, L.L. 1985. A Conceptual Model of Service Quality and Its Implications for Future Research. Journal of Marketing 49, no. 4: 41. doi:10.2307/1251430

Salvador-Ferrer, C.M. 2009. Structural equation models for Predicting Customer Expectation, satisfaction and perceived Quality relationships. International Journal of Academic research 1, no. 1: 147-152.

Schermelleh-Engel, K., Moosbrugger, H., and Müller, H. 2003. Evaluating the Fit of Structural Equation Models: Tests of Significance and Descriptive Goodness-of-Fit Measures. Psychological Research 8, no. 2: 23-74.

Schumacker, R.E., and Lomax, R.G. 2004. A Beginner's Guide to Structural Equation Modeling. London: Lawrence Erlbaum Associates.

Steiger, J.H. 2007. Understanding the limitations of global fit assessment in structural equation modeling. Personality and Individual Differences 42, no. 5: 893-898. doi:10.1016/j. paid.2006.09.017

Sumaedi, S., Bakti, I., and Metasari, N. 2011. The effect of students' perceived service quality and perceived price on student satisfaction. Management Science and Engineering 5, no. 1: 88-97.

Vergara-Schmalbach, J.C., and Quesada, V.M. 2011. Revista Electrónica de Investigación Educativa Análisis de la calidad en el servicio y satisfacción de los estudiantes de Ciencias Económicas de la Universidad de Cartagena mediante un modelo de ecuaciones estructurales Analysis of the Quality of Service. Redie 13, no. 1: 108-122.

Zeithaml, V.A. 1981. How Consumer Evaluation Processes Differ Between Goods and Service. Marketing of Service 9, no. 1: 186-190. 